\title{
A Survey of Viruses Found in Grapevine Cultivars Grown in Missouri
}

\author{
James Schoelz, ${ }^{1 *}$ Dean Volenberg, ${ }^{1}$ Mustafa Adhab ${ }^{2}$ Zhiwei Fang, ${ }^{1}$ \\ Vicki Klassen, ${ }^{3}$ Christine Spinka, ${ }^{1}$ and Maher Al Rwahnih ${ }^{3}$
}

\begin{abstract}
In 2017 a survey was initiated of vineyards throughout Missouri for the presence of 19 different grapevine viruses. A total of 400 samples were collected from 25 grape cultivars, with a sample consisting of 16 petioles (four petioles from four different vines). Sampling within vineyard blocks was random, without regard to the presence or absence of symptoms. After nucleic acids were extracted from petiole samples, nucleic acid samples were analyzed using reverse transcriptase-quantitative polymerase chain reaction (RT-qPCR) to detect viral RNA/DNA. At least one virus was detected in $90 \%$ of the samples. The most common virus detected in the survey was grapevine rupestris stem pitting-associated virus, which was found in $59 \%$ of the samples, followed by grapevine leafrollassociated virus $3(53 \%)$, grapevine red blotch virus (35\%), grapevine virus E (31\%), grapevine leafroll-associated virus 2 (19\%), grapevine virus B (17\%), grapevine fleck virus (13.5\%), grapevine leafroll-associated virus-2 Redglobe $(9 \%)$, grapevine vein clearing virus $(8 \%)$, grapevine virus A $(0.5 \%)$, and grapevine leafroll-associated virus 4 strain $5(0.2 \%)$. Two or more viruses were detected in $\sim 65 \%$ of the samples, with an upper limit of seven viruses detected in one sample. An analysis of the survey results indicated that each grapevine cultivar appears to be infected by specific virus combinations that are, for the most part, unique to that cultivar.
\end{abstract}

Key words: grapevine cultivar, grapevine leafroll disease, grapevine red blotch virus, grapevine vein clearing virus, Rugose wood complex, virus

One of the keys for production of quality perennial plants and plant products is a comprehensive plan for the detection and mitigation of diseases caused by plant pathogens. This process begins with the planting of perennials that have been certified to be free of specific plant pathogens and continues with periodic testing to ensure that plants remain pathogenfree. Grapevines are one horticultural crop that has benefited from production of clean stock and from routine testing. In particular, grapevines are susceptible to over 86 different plant viruses (Fuchs 2020). Multiple viruses may accumulate in a grapevine over its life span, and individual viruses, or combinations of different viruses, may have detrimental effects on the physiology of the vine, yield of grape berries from the vine, and berry quality (Ricketts et al. 2015, 2017, Martelli 2017).

Winegrapes in Missouri are grown on $\sim 1700$ acres by 450 growers, and are used by more than 130 wineries for

\footnotetext{
${ }^{1}$ Division of Plant Sciences, University of Missouri, Columbia, MO 65211; ${ }^{2}$ Department of Plant Protection, University of Baghdad, Baghdad, Iraq 10071; and ${ }^{3}$ Department of Plant Pathology, University of California, Davis, CA 95616. *Corresponding author (schoelzj@missouri.edu; tel: 573-882-1185)

Acknowledgments: The authors thank Jia Cheng for technical assistance. This project was supported by grants to J.S. and D.V. from the Missouri Grape and Wine Research Board in 2017 and 2018 and by the Missouri Agricultural Experiment Station.

Manuscript submitted July 2020, revised Sept 2020, accepted Sept 2020

This is an open access article distributed under the CC BY license (https:// creativecommons.org/licenses/by/4.0/).

By downloading and/or receiving this article, you agree to the Disclaimer of Warranties and Liability. The full statement of the Disclaimers is available at http://www.ajevonline.org/content/proprietary-rights-notice-ajev-online. If you do not agree to the Disclaimers, do not download and/or accept this article. doi: 10.5344/ajev.2020.20043
}

wine production (USDA Natl. Ag Statistics Service Missouri 2016). The most common cultivars grown in Missouri are French-American hybrids (hereafter referred to as hybrids) such as Chambourcin, Vidal blanc, Vignoles, and Chardonel, or American grapes such as Norton/Cynthiana (Vitis aestivalis) and Concord (Vitis labrusca), rather than the Vitis vinifera cultivars grown on the West Coast and elsewhere in the United States. Consequently, a comprehensive survey of viruses in Missouri vineyards could reveal the current status of the most common and damaging viruses in the Midwest region of the U.S., as well as that of viruses commonly found in native and hybrid grapes.

Previous surveys for grapevine viruses in Missouri were limited in scope and geography, focusing primarily on only a few locations in the state and a few viruses. For example, Milkus (2001) surveyed five commercial vineyards in Missouri for the presence of the nepoviruses: grapevine fanleaf virus (GFLV), tobacco ringspot virus (TRSV), tomato ringspot virus (ToRSV), and Arabis mosaic virus (ArMV). Only Catawba, Norton, Seyval blanc, Vidal blanc, and St. Vincent were surveyed. It was found that the prevalence of ToRSV ranged from $28 \%$ (Vidal blanc) to $42 \%$ (St. Vincent) in the five cultivars, and 0 to $39 \%$ for ArMV, whereas GFLV and TRSV were not detected. Interestingly, none of the vines infected with ToRSV or ArMV showed symptoms of a virus infection.

Milkus and Goodman (1999) used enzyme-linked immunosorbent assay (ELISA) to survey five vineyards for six grapevine viruses. A total of 334 single-leaf samples were tested and the most commonly detected virus was grapevine leafroll-associated virus 3 (GLRaV-3). GLRaV-3 was detected at five of six vineyard locations, and its prevalence in the seven 
cultivars tested varied from $100 \%$ in Catawba at one location, to $0 \%$ in Chambourcin. Grapevine fleck virus $(\mathrm{GFkV})$ and grapevine virus A (GVA) were also found in Norton and Vignoles, whereas GFLV and grapevine leafroll-associated virus 1 (GLRaV-1) were not detected in any samples. In addition to the limited surveys for grapevine viruses, little research has been conducted on the impact of viruses on hybrid grapevine physiology. Kovacs et al. (2001) examined the impact of GLRaV-3 on Vidal blanc and St. Vincent cultivars, showing that GLRaV-3 caused a reduction in berry weight and an increase in titratable acid levels.

Grapevine vein clearing disease was first observed in a Chardonnay vineyard in Missouri in 2004 (Qiu et al. 2007). High-throughput sequencing of small RNAs collected from a symptomatic vine indicated that the causal agent was a badnavirus, and its complete nucleotide sequence was assembled through PCR amplification and cloning of the viral DNA (Zhang et al. 2011). The virus, grapevine vein clearing virus (GVCV), has been found in several $V$. vinifera cultivars and interspecific grape hybrids, as well as wild grapes (Vitis rupestris) and heartleaf peppervine (Ampelopsis cordata), throughout the Midwest U.S. (Guo et al. 2014, Beach et al. 2017, Peterson et al. 2019). Two grape hybrid cultivars, Chambourcin and Norton, have been reported to be resistant to GVCV (Guo et al. 2014, Qiu et al. 2020). GVCV has recently been shown to be transmitted from $A$. cordata to Chardonel by the grape aphid (Aphis illinoisensis); thus A. cordata can serve as a natural reservoir for GVCV to be transmitted to vineyards by the grape aphid (Peterson et al. 2019).

In addition, in 2016, the geminivirus grapevine red blotch virus (GRBV) was detected in the cultivar Crimson Cabernet in one Missouri vineyard (Schoelz et al. 2019). Red blotch disease was first recognized in 2008 in a Cabernet Sauvignon vineyard in California (Calvi 2011). The causal agent, a virus, was independently characterized in New York and California (Krenz et al. 2012, Al Rwahnih et al. 2013), and Koch's postulates were completed in 2018, proving that GRBV was the causal agent of red blotch disease (Yepes et al. 2018). It is now considered to be widespread in North America (Krenz et al. 2014). With the exception of the one Crimson Cabernet vineyard in Missouri, little is known about the prevalence of GRBV in other hybrid grape cultivars grown in Missouri.

In 2017 we surveyed 25 different hybrid or American grapevine cultivars located at 17 vineyards across the state of Missouri for the presence of 19 viruses commonly found in grapes. A more limited follow-up survey in 2018 was designed to specifically examine the prevalence of GRBV in hybrid grape cultivars grown in Missouri.

\section{Materials and Methods}

Sample collection in 2017, processing, and analysis by quantitative real-time PCR. Four hundred samples were obtained from Missouri vineyards in June and July 2017. Samples were collected without taking into account the presence of symptoms in a prearranged pattern corresponding to the shape of a "W" within the vineyard block. The first and last samples and last samples were taken approximately three rows from the edge of the vineyard block and two-thirds down the length of the row. Each sample was a composite, consisting of 16 leaves with petioles; four leaves were collected from each of four vines, with two leaves selected from each cordon. Samples at one location were taken from two adjacent vines and the vines directly across from them. We typically collected 10 composite samples from a vineyard block, but in some blocks we collected only five composite samples due to vineyard size. Consequently, a total of 1600 vines were sampled in the survey. Samples were maintained in a cooler with ice during collection and transport to the laboratory. Composite samples were processed by cutting slices from each of the petioles in the sample, for a total fresh weight of $80 \mathrm{mg}$ per composite sample. One complete set of the 400 composite samples was shipped to Foundation Plant Services (FPS) at UC Davis for further processing, and a second complete set was stored in a $-80^{\circ} \mathrm{C}$ freezer at the University of Missouri.

At FPS, the total nucleic acids (TNA) were isolated from each of the plant samples and then assayed for 19 different viruses by reverse transcriptase-quantitative PCR (RT-qP$\mathrm{CR})$. Approximately $0.30 \mathrm{~g}$ frozen petioles were transferred to extraction bags (Product \# 430100, BioReba AG) that contained $3 \mathrm{~mL}$ of guanidine isothiocyanate lysis buffer $(4 \mathrm{M}$ guanidine isothiocyanate; $0.2 \mathrm{M}$ sodium acetate, $\mathrm{pH} 5.0 ; 2$ mM EDTA; 2.5\% [w/v] PVP-40) and homogenized using a HOMEX grinder (Product \# 400014, BioReba AG). One mL of lysate was transferred to a 96-well deep well plate and stored at $-20^{\circ} \mathrm{C}$. TNA extracts were prepared from $400 \mu \mathrm{L}$ lysate using the MagMAX Express 96 and the MagMAX-96 Total RNA Isolation Kit (www.thermofisher.com) according to the manufacturer's specifications. The integrity of RNA was verified using an 18S rRNA assay (Osman and Rowhani 2006). RT-qPCR reactions were done in the QuantStudio 6 Flex Real-time PCR system using the TaqMan Fast Virus 1-Step Master Mix (www.thermofisher.com). Each $10 \mu \mathrm{L}$ reaction included $2 \mu \mathrm{L}$ TNA and final primer and probe concentrations of 900 and $250 \mathrm{nmol}$, respectively.

The viruses included in the survey are listed in Table 1. Primers and probes used for the detection of these viruses were used as described in the literature: GLRaV-1, GLRaV-2, GLRaV-4, GLRaV-4 strain 5, GLRaV-4 strain 9 (Osman et al. 2007); GLRaV-7 (Al Rwahnih et al. 2011); grapevine rupestris stem pitting-associated virus (GRSPaV) (Osman and Rowhani 2008); GVA, GVB, and GVD (Osman et al. 2013); GFLV (Osman and Rowhani 2006); GFkV, grapevine leafroll-associated virus 2 isolate Redglobe (GLRaV-2RG), and ToRSV (Osman et al. 2008); GLRaV-3 (Diaz-Lara et al. 2018); and grapevine Pinot gris virus (GPGV) (Al Rwahnih et al. 2016). For all other viruses (ArMV, TRSV, grapevine red blotch virus [GRBV], GVCV, grapevine virus E [GVE], grapevine virus $F$ [GVF], GLRaV-3 strain e, GLRaV-4 strain 6, GLRaV-4 strain Pr, and GLRaV-4 strain Car), primers and probes developed at FPS were used (Al Rwahnih, unpublished data). In the case of phytoplasmas, a universal assay that detects all known phytoplasmas was used (Hodgetts et al. 2009). Lastly, probes and primers designed by Schaad et al. (2002) were used for 
Xylella fastidiosa. These primers and probes are part of the routine testing procedure at FPS.

To verify the GRBV results obtained at FPS, GRBV infection status was evaluated in selected duplicate samples stored at the University of Missouri. Total DNA was isolated using a DNeasy plant mini kit (Qiagen) and GRBV DNA was amplified by PCR using PfuUltra II Fusion HS DNA polymerase (Agilent). The PCR primers (2866For 5'AAGGCGTGTAGGTGTGGCTC3' and 119Rev 5'ACGGATCCAGCGTCTAAGC3') amplified a 461-bp DNA segment spanning the region of nucleotides 2866 to 119 . PCR conditions were $94^{\circ} \mathrm{C}$ for 5 min, followed by 35 cycles of $94^{\circ} \mathrm{C}$ for $30 \mathrm{sec}, 55^{\circ} \mathrm{C}$ for 30 sec, $72^{\circ} \mathrm{C}$ for $30 \mathrm{sec}$, and $72^{\circ} \mathrm{C}$ for $10 \mathrm{~min}$.

Sample collection in 2018, processing, and PCR analysis for GRBV. For the 2018 survey for GRBV, individual Chambourcin and Norton vines were sampled in late June at three locations that tested positive for GRBV in the 2017 survey. Samples were collected in a prearranged pattern without taking into account the presence of symptoms. At each location, eight vines were sampled from each of five rows. Four leaves were collected from every fifth vine in the row, with two leaves selected from each cordon. In addition, 10 vines of Crimson Cabernet were selected randomly from a single location. Samples were maintained in a cooler with ice during collection and transport to the laboratory. Total DNA was isolated using a DNeasy plant mini kit (Qiagen) and GRBV DNA was amplified by PCR using GoTaq Polymerase (Promega). The PCR primers (621For 5'TCAACTGAGTAGACGCGTTGC3' and 1261Rev 5'TCAACATCATTCCGTCCTCCA3') amplified a 640-bp DNA segment spanning the region of nucleotides 621 to 1261 . PCR conditions were $94^{\circ} \mathrm{C}$ for 5 min, followed by 30 cycles of $94^{\circ} \mathrm{C}$ for $30 \mathrm{sec}, 50^{\circ} \mathrm{C}$ for 30 sec, $72^{\circ} \mathrm{C}$ for $30 \mathrm{sec}$, and $72^{\circ} \mathrm{C}$ for $10 \mathrm{~min}$.

Evaluation of Norton and Chambourcin for symptoms of GRBV. To determine whether GRBV symptoms could be observed in Norton and Chambourcin leaves, 20 individual Chambourcin and 20 Norton leaves were collected in late September in 2018. Where possible, some samples were selected for the characteristic interveinal reddening associated with GRBV in red-berried $V$. vinifera cultivars, whereas others were lacking any obvious symptoms. Samples were maintained in a cooler with ice during collection and transport to the laboratory, where individual leaves were photographed and then scored for the presence or absence of the GRBV virus by PCR. Total DNA isolation and PCR analysis were as described in the previous section.

Statistical analysis of the $\mathbf{2 0 1 7}$ survey. An examination of the data suggested that certain combinations of viruses occurred together in particular cultivars more often than would be seen by chance. Permutation tests of goodness of fit (Fişek and Barlas 2013) were performed to determine if the presence of one virus in a sample affected the likelihood of seeing other viruses. Additionally, three cultivars, Chardonel, Norton, and Vignoles, were found together at each of three locations; for this reason, these cultivars and locations were selected for further study. Likelihood ratio tests for non-nested models (Williams 1970, Lewis et al. 2011) were used to compare various models for the distribution of viruses in cultivars and vineyards. All model fitting and analysis was performed within $\mathrm{R}$, and $p$ values were determined through simulation.

Table 1 Grapevine viruses tested for ${ }^{\mathrm{a}}$ and grapevine viruses detected ${ }^{\mathrm{b}}$ in the 2017 survey. $^{\mathrm{c}}$

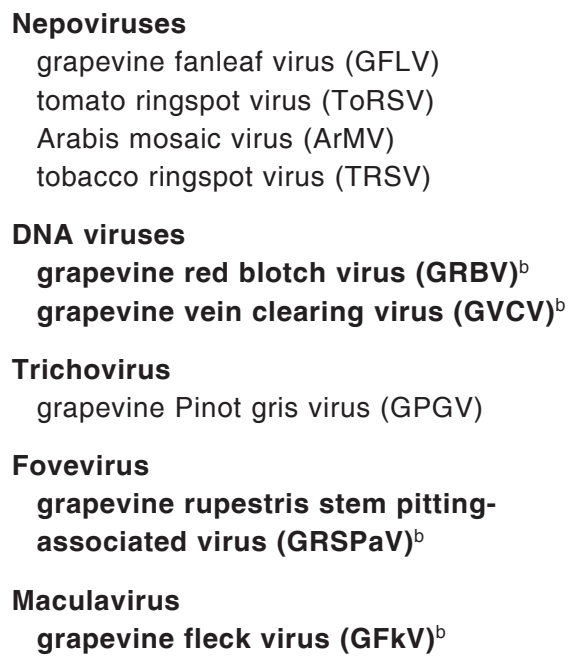

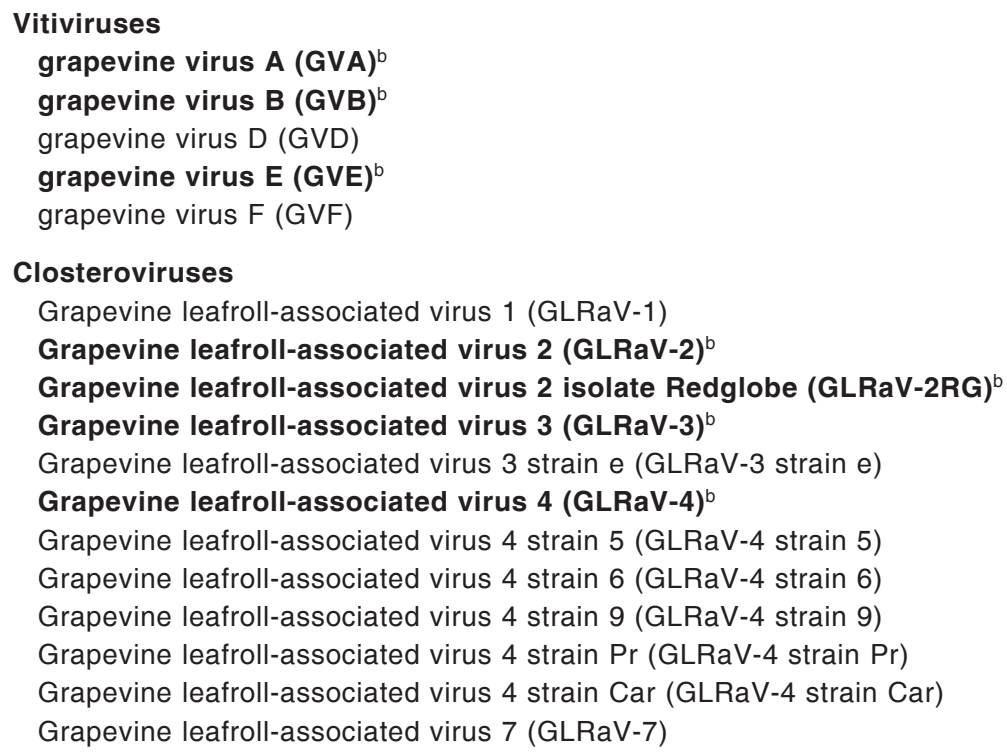

\footnotetext{
${ }^{a}$ Total nucleic acid samples were extracted from petioles and analyzed using reverse transcriptase-quantitative polymerase chain reaction (RT-qPCR) to detect viral RNA/DNA.

${ }^{b}$ Viruses in bold were detected in the survey.

${ }^{\mathrm{C}} \mathrm{A}$ total of 25 grape cultivars were surveyed for a total of 400 samples. A sample was 16 petioles (four petioles from four different grapevines). Sampling was random in vineyard blocks without regard to presence or absence of symptoms.
} 


\section{Results}

A total of 25 grape cultivars were sampled, and the results for each cultivar are summarized in Table 2. In addition, all samples were negative for X. fastidiosa and one composite sample was positive for a phytoplasma (data not shown). The top three most prevalent viruses in grapevine cultivars grown in Missouri were GRSPaV, GLRaV-3, and GRBV, with a prevalence of $58.7 \%, 52.7 \%$, and $35.0 \%$, respectively (Table 2). However, a discussion of the average incidence masks the true distribution of the viruses in hybrid grape cultivars. For example, $58.7 \%$ of the samples contained GRSPaV, but $100 \%$ of the Vidal blanc samples contained this virus, whereas GRSPaV was not detected in any of the 40 composite samples of Norton (Table 2). Consequently, it is more informative to look at the virus composition in individual cultivars rather than the average results from the survey. The major findings of the survey are summarized below.

GRBV was prevalent in a majority of the grape cultivars surveyed in 2017. GRBV was first discovered in Missouri in 2016 in the cultivar Crimson Cabernet (Schoelz et al. 2019). The 2017 survey revealed the widespread occurrence of GRBV in hybrid grape cultivars, as GRBV was detected in 15 of the 25 grape cultivars and at 28 locations across Missouri
(Table 2). GRBV was detected in six of the seven cultivars most widely grown in Missouri (USDA Natl. Ag Statistics Service Missouri 2016). GRBV was detected in $~ 75 \%$ of Chardonel and Norton samples, and in $\sim 20$ to $27 \%$ of Vidal blanc, Chambourcin, and Concord samples. By contrast, only $4.3 \%$ of Vignoles samples were positive for GRBV, and GRBV was not detected in any of the Catawba samples (Table 2).

To verify the results of the RT-qPCR assay, two samples from each location/cultivar that tested positive for GRBV were selected from the duplicate set of petioles stored at $-80^{\circ} \mathrm{C}$ in Missouri and total DNA was isolated for a conventional PCR analysis. The only exceptions to this scheme occurred with the cultivars Albania and Vidal blanc at one of two locations, as only one of the composite samples at these locations was shown to be positive for GRBV. GRBV was shown to be present in the analysis of all 54 duplicate samples tested, confirming the results of the initial RT-qPCR assay (data not shown).

Because all samples collected in 2017 were composites of four vines, the infection rate in a sample testing positive for a virus could range from 25 to $100 \%$. To acquire a more accurate assessment of GRBV in Missouri, we followed up in July 2018 with testing of individual vines of Norton, Chambourcin, and Crimson Cabernet at several locations (Table 3). In

Table 2 Virus prevalence in each grape cultivar.

\begin{tabular}{|c|c|c|c|c|c|c|c|c|c|c|c|c|}
\hline \multirow[b]{2}{*}{ Cultivar } & \multirow[b]{2}{*}{$\begin{array}{c}\text { No. of } \\
\text { samples }^{a}\end{array}$} & \multicolumn{11}{|c|}{ Percentage of composite samples in a cultivar that tested positive for each virus } \\
\hline & & GRSPaV & GLRaV-3 & GRBV & GVE & GLRaV-2 & GVB & GVkV & $\begin{array}{l}\text { GLRaV- } \\
\text { 2RG }\end{array}$ & GVCV & GVA & $\begin{array}{c}\text { GLRaV-4 } \\
\text { str5 }^{\mathrm{b}}\end{array}$ \\
\hline Vignoles & 70 & 100 & 88.5 & 4.3 & 85.7 & 54.2 & 65.7 & 38.5 & 1.4 & 1.4 & 0 & 0 \\
\hline Vidal blanc & 45 & 100 & 91.1 & 24.4 & 26.7 & 91.1 & 0 & 28.9 & 0 & 33.3 & 0 & 0 \\
\hline Chardonel & 45 & 46.7 & 33.3 & 75.5 & 8.9 & 6.7 & 0 & 0 & 0 & 24.4 & 0 & 2.2 \\
\hline Norton & 40 & 0 & 85.5 & 77.5 & 30.0 & 0 & 22.5 & 15.0 & 72.5 & 0 & 2.5 & 0 \\
\hline Chambourcin & 30 & 100 & 3.3 & 26.7 & 0 & 26.7 & 0 & 3.3 & 0 & 0 & 3.3 & 0 \\
\hline Valvin Muscat & 20 & 100 & 10.0 & 40.0 & 0 & 0 & 0 & 0 & 0 & 20.0 & 0 & 0 \\
\hline Vivant & 20 & 15.0 & 10.0 & 0 & 0 & 0 & 0 & 0 & 0 & 0 & 0 & 0 \\
\hline Traminette & 11 & 36.4 & 0 & 0 & 0 & 0 & 0 & 0 & 0 & 0 & 0 & 0 \\
\hline Cayuga & 10 & 0 & 50.0 & 0 & 0 & 0 & 0 & 0 & 0 & 10.0 & 0 & 0 \\
\hline Concord & 10 & 0 & 100 & 20.0 & 100 & 0 & 10.0 & 0 & 0 & 0 & 0 & 0 \\
\hline $\begin{array}{l}\text { Crimson } \\
\text { Cabernet }\end{array}$ & 10 & 0 & 0 & 90.0 & 0 & 0 & 0 & 0 & 0 & 0 & 0 & 0 \\
\hline Noiret & 10 & 0 & 0 & 60.0 & 0 & 0 & 0 & 0 & 0 & 10.0 & 0 & 0 \\
\hline Rayon & 10 & 100 & 50.0 & 0 & 0 & 20.0 & 10.0 & 40.0 & 60.0 & 0 & 0 & 0 \\
\hline Vincent & 10 & 80.0 & 0 & 0 & 0 & 0 & 0 & 0 & 0 & 0 & 0 & 0 \\
\hline Viognier & 10 & 100 & 0 & 20.0 & 0 & 0 & 0 & 0 & 0 & 10.0 & 0 & 0 \\
\hline Albania & 5 & 0 & 100 & 20.0 & 100 & 0 & 40.0 & 0 & 0 & 0 & 0 & 0 \\
\hline Cabernet franc & 5 & 100 & 0 & 0 & 0 & 0 & 0 & 0 & 0 & 0 & 0 & 0 \\
\hline Catawba & 5 & 0 & 100 & 0 & 80.0 & 0 & 80.0 & 0 & 0 & 0 & 0 & 0 \\
\hline Cloeta & 5 & 0 & 100 & 0 & 0 & 0 & 0 & 0 & 0 & 0 & 0 & 0 \\
\hline Hidalgo & 5 & 0 & 40.0 & 80.0 & 40.0 & 0 & 0 & 0 & 0 & 0 & 0 & 0 \\
\hline Lenoir & 5 & 0 & 40.0 & 100 & 0 & 100 & 60.0 & 0 & 0 & 0 & 0 & 0 \\
\hline Marechal Foch & 5 & 100 & 100 & 100 & 0 & 0 & 0 & 40.0 & 0 & 0 & 0 & 0 \\
\hline Muench & 5 & 0 & 100 & 0 & 100 & 0 & 20.0 & 0 & 0 & 0 & 0 & 0 \\
\hline Wetumka & 5 & 0 & 100 & 100 & 100 & 0 & 100 & 0 & 0 & 0 & 0 & 0 \\
\hline Saperavi & 4 & 100 & 0 & 0 & 0 & 0 & 0 & 0 & 0 & 0 & 0 & 0 \\
\hline Survey averagec & 400 & 58.7 & 52.7 & 35.0 & 31.0 & 19.0 & 17.2 & 13.5 & 9.2 & 8.2 & 0.5 & 0.2 \\
\hline
\end{tabular}

aThe number of composite samples (16 petioles, four petioles from four different grapevines) collected for each cultivar.

${ }^{b}$ GLRaV-4 strain 5, abbreviated to GLRaV-4 str5.

${ }^{\mathrm{c}}$ The overall percentage of composite samples positive for each virus. 
general, the testing of individual vines in 2018 confirmed the results obtained with the composite samples in 2017 (Table 3). For example, at three of the four sites in which $100 \%$ of the composite samples tested positive for GRBV, its prevalence was above $25 \%$. In one Norton block, GRBV was detected in $15 \%$ of the vines tested individually (six out of 40 vines tested positive). Furthermore, the two sites at which composite vines were negative for GRBV in 2017 remained negative upon testing of individual vines in 2018.

Prior to 2017, the only cultivar in Missouri that appeared to have any evidence of GRBV symptoms was Crimson Cabernet. GRBV symptoms in Crimson Cabernet are characterized by interveinal redness that develops late in the growing season (Figure 1A), whereas uninfected leaves remain green (Figure 1D). Symptom expression in Crimson Cabernet infected with GRBV can anecdotally be attributed to genetic parentage, as Crimson Cabernet is $62.5 \%$ V vinifera and

Table 3 Prevalence of GRBV in Norton, Chambourcin, and Crimson Cabernet composite samples and individual vine samples at selected sites.

\begin{tabular}{lcc}
\hline Cultivar/location & $\begin{array}{c}\text { Composite samples } \\
\text { collected in 2017 }\end{array}$ & $\begin{array}{c}\text { Individual samples } \\
\text { collected in 2018 }^{b}\end{array}$ \\
\hline Norton/Hermann & $0 / 5^{\mathrm{d}}(0 \%)^{\mathrm{e}}$ & $0 / 40(0 \%)$ \\
Norton/Hermann & $5 / 5(100 \%)$ & $6 / 40(15 \%)$ \\
Norton/Central & $5 / 5(100 \%)$ & $33 / 40(83 \%)$ \\
Chambourcin/Hermann & $0 / 5(0 \%)$ & $0 / 40(0 \%)$ \\
Chambourcin/Hermann & $5 / 5(100 \%)$ & $13 / 40(33 \%)$ \\
Chambourcin/Central & $3 / 5(60 \%)$ & $29 / 40(73 \%)$ \\
Crimson Cabernet/ & $5 / 5(100 \%)$ & $10 / 10(100 \%)$ \\
Hermann & &
\end{tabular}

${ }^{a}$ Composite sample consisted of four leaves from four vines. 'Individual samples consisted of four leaves from a single vine.

${ }^{c} V i n e s$ at this location were planted before 1860.

${ }^{d}$ First number represents number of samples testing positive for grapevine red blotch virus (GRBV) and the second number represents total number of samples tested.

eNumber within parentheses represents \% of samples infected with GRBV.
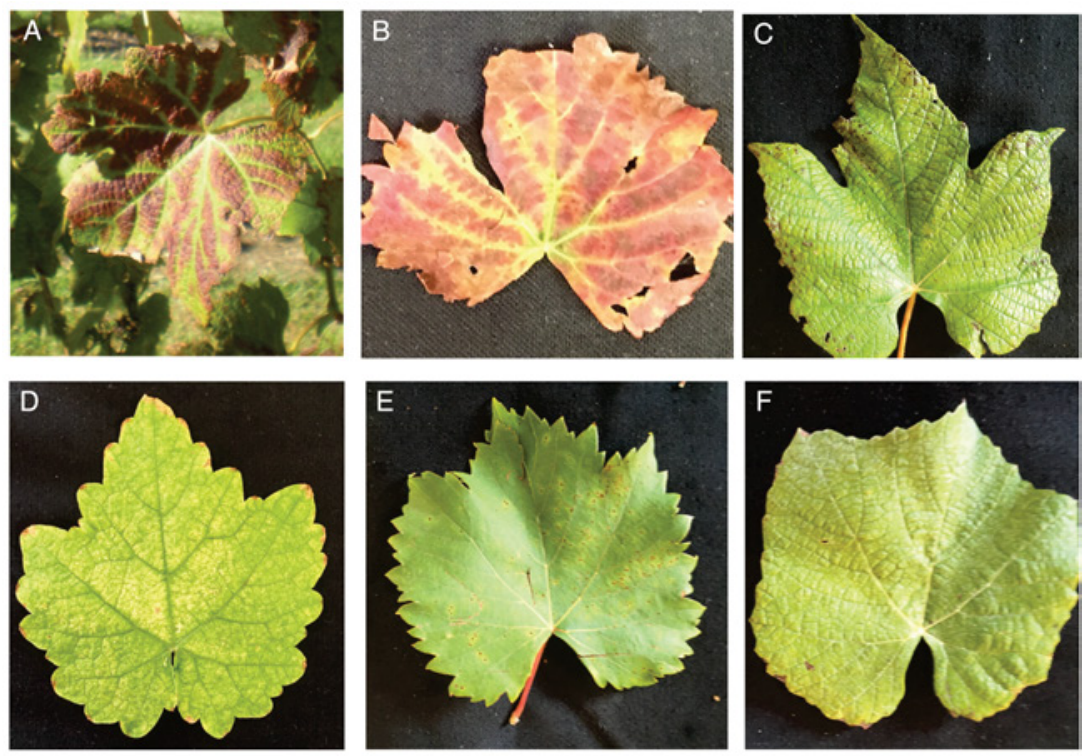

$37.5 \% \mathrm{~V}$. aestivalis. To determine whether the typical GRBV symptom of interveinal reddening could be observed in Norton and Chambourcin leaves, representative leaves from 20 vines for each cultivar were collected in late September in 2018 and tested for the presence of GRBV. Figure 1 illustrates representative Chambourcin and Norton leaves that tested either positive or negative for GRBV. GRBV infection in Chambourcin was associated with a bright red symptom in the interveinal tissue, with the veins remaining green (Figure 1B). Seven of the eight Chambourcin leaves that tested positive for GRBV exhibited a reddening of the interveinal tissue. By contrast, the 12 Chambourcin leaves negative for GRBV were free of any reddish color (Figure 1E). In the case of Norton, no discernible differences were observed between the five GRBV-positive leaves and the 15 leaves that were negative for GRBV (representative leaves illustrated in Figure 1C and $1 F$ ), indicating that at the level of symptomatology, Norton appears asymptomatic for infection by GRBV. It is important to note that symptoms of GRBV infection can be confused with symptoms for GLRaVs, particularly GLRaV-3. Significantly, the site chosen for sampling Chambourcin leaves had been found in the 2017 survey to be free of GLRaV-3, so we could assess the potential contribution of GRBV by itself to symptomatology in infected vines. This was not the case for Norton, as the 2017 survey showed that $85 \%$ of Norton samples were infected with GLRaV-3, although Norton also appeared to be free of symptoms of GLRaV-3 (Volenberg and Schoelz, personal communication).

Grapevine leafroll viruses were prevalent in a majority of the hybrid grape cultivars sampled in 2017. Two distinct leafroll viruses (GLRaV-3 and GLRaV-2/GLRaV-2RG) were detected at a high prevalence in the 2017 survey, whereas a third virus (GLRaV-4 strain 5) was found in only one of the 400 composite samples (Table 2). Of these three viruses, GL$\mathrm{RaV}-3$ is considered the most important causal agent of grapevine leafroll disease (Maree et al. 2013). In the 2017 survey for GLRaV-3 in Missouri, GLRaV-3 was found in 18 of the 25 grape hybrid cultivars surveyed and overall was detected in
Figure 1 Representative leaves of Crimson Cabernet, Chambourcin, and Norton that were either positive or negative for grapevine red blotch virus (GRBV). A to C: Crimson Cabernet, Chambourcin, and Norton samples, respectively, that were PCR-positive for GRBV. D to F: Crimson Cabernet, Chambourcin, and Norton samples, respectively, that were PCR-negative for GRBV. 
$52.7 \%$ of all samples (Table 2). For the grape cultivars Vidal blanc, Vignoles, and Norton sampled at five or more locations, GLRaV-3 was detected at a very high level (over 85\%). GLRaV-3 was also detected at high levels in Concord, Muench, Wetumka, Albania, Catawba, and Marechal Foch (Table 2). However, for these cultivars the sample size was small and typically came from only one location, so it is not possible to state whether the high levels of infection are indicative of GLRaV-3 levels across the state for those cultivars.

In the 2017 statewide survey for viruses in Missouri, GL$\mathrm{RaV}-2$ was found in six and GLRaV-2RG was found in three of the 25 hybrid grape cultivars surveyed (Table 2). Although these viruses were not as widely detected as GLRaV-3, there were some cultivars in which the prevalence was high. For example, GLRaV-2RG was detected in $72.5 \%$ of the 40 Norton samples collected from six vineyards (Table 2), whereas GLRaV-2 was found in $91.1 \%$ of Vidal blanc, $54.2 \%$ of Vignoles, and $26.7 \%$ of Chambourcin samples.

GVCV was detected almost exclusively in white-berried cultivars. GVCV, a grapevine virus that was first discovered and characterized in Missouri (Zhang et al. 2011, Guo et al. 2014), was detected in $8.2 \%$ of the composite samples taken during the 2017 survey (Table 2). The low incidence of GVCV in the survey was likely skewed by the observation that GVCV was absent from all red-berried cultivars, with the exception of Noiret. In fact, GVCV was detected at moderate levels of $33.3 \%, 24.4 \%$, and $20.0 \%$, in Vidal blanc, Chardonel, and Valvin Muscat, respectively (Table 2). Consequently, GVCV might be considered a significant problem for specific white grape cultivars, but may not be an issue for red grape cultivars. Recently, it was shown that Chambourcin is resistant to GVCV (Guo et al. 2014); it may be that resistance may be found in other red grape cultivars as well.

The incidence of some viruses varied with the age of the vineyard, whereas incidence for other viruses was independent of vineyard age. As part of the 2017 survey, we queried the vineyard managers to determine the year in which the vineyard was planted. To examine the effect of grapevine age on the incidence of each of the viruses, vineyards were divided into four categories. The grapevine samples from most of the vineyards fell within the three categories of less than 10-years-old, 11- to 20-years-old, and 21- to 40-years-old. The fourth category, consisting of a single Norton vineyard block that was estimated to be at least 156 years old, provided an interesting contrast with more recent plantings. Several pat- terns were apparent in this analysis. With many viruses, virus incidence was lowest in the youngest vineyard blocks and the viruses accumulated as vines increased in age. For example, the incidence of GLRaV-3 was $36.0 \%$ in the youngest vines, $48.1 \%$ in vines from 11 to 20 years of age, and $74.5 \%$ in vines from 21 to 40 years of age (Table 4). This pattern was similar to another recent survey for GLRaV-3 in $V$. vinifera grapes conducted in Ontario, in which the authors recorded percent incidences of 37.8, 55.7, and 71.1 for grapevine samples of ascending ages (Xiao et al. 2018). Other viruses that conformed to this pattern included GLRaV-2, GLRaV-2RG, GVE, GVB, and GVCV (Table 4). By contrast, the incidence of GRBV appeared to be independent of vineyard age, with one important exception (Table 4). GRBV was absent from the five composite Norton samples that were over 156 years of age. In a follow-up survey in 2018 specifically at this location, 40 vines were tested individually for GRBV and all were negative, providing further evidence that GRBV was absent from this Norton vineyard.

The most commonly grown grape cultivars in Missouri were typically infected with multiple viruses. The 2017 survey found that $90.2 \%$ of the composite samples contained at least one virus. Two or more viruses were detected in $\sim 65 \%$ of the samples, with an upper limit of seven viruses detected in one sample. Interestingly, an analysis of the survey results indicated that grapevine cultivars appeared to be infected by specific virus combinations that are, for the most part, unique to that cultivar. This is most clearly seen in three of the cultivars most commonly grown in Missouri, the cultivars Vignoles, Norton, and Vidal blanc.

Every one of the 70 composite samples collected for Vignoles contained two or more viruses (Table 5). GRSPaV was present in every sample, whereas GLRaV-3 was detected in $90 \%$ of them. By contrast, GRBV and GVCV were nearly absent from the samples of Vignoles, as GRBV and GVCV were found in $4.2 \%$ and $1.4 \%$ of the composite samples, respectively. One of the strengths of the survey is that multiple Vignoles vineyards were surveyed, revealing that virus combinations discovered in Vignoles were largely unique to Vignoles (Table 5, all combinations highlighted in bold). For example, composite samples containing GRSPaV, GLRaV-3, GVB, and GVE (Table 5, highlighted in bold lettering) were found at five different vineyards, and this combination occurred only with Vignoles. Interestingly, three of the Vignoles vineyard blocks were derived from the same nursery, whereas

Table 4 Virus prevalence in grape cultivars based on vine age.

Percentage of composite samples that tested positive for each virus

\begin{tabular}{|c|c|c|c|c|c|c|c|c|c|c|c|c|}
\hline \multirow[b]{2}{*}{ Age $^{a}$} & \multirow[b]{2}{*}{$\begin{array}{c}\text { No. of } \\
\text { samples }\end{array}$} & \multicolumn{11}{|c|}{ Percentage of composite samples that tested positive for each virus } \\
\hline & & GRSPaV & GLRaV-3 & GRBV & GVE & GLRaV-2 & GVB & GVkV & $\begin{array}{c}\text { GLRaV- } \\
\text { 2RG }\end{array}$ & GVCV & GVA & GLRaV-5 \\
\hline 1 to 10 & 125 & 79.2 & 36.0 & 41.6 & 12.0 & 16.0 & 8.0 & 11.2 & 0.8 & 4.8 & 0.8 & 0 \\
\hline 11 to 20 & 160 & 49.4 & 48.1 & 31.2 & 37.5 & 16.2 & 20.6 & 11.8 & 4.3 & 6.8 & 0 & 0 \\
\hline 21 to 40 & 110 & 45.4 & 74.5 & 37.2 & 34.5 & 27.2 & 21.8 & 15.4 & 17.2 & 12.7 & 0.9 & 0.9 \\
\hline 156 & 5 & 0 & 100 & 0 & 100 & 100 & 0 & 0 & 0 & 0 & 0 & 0 \\
\hline Total & 400 & 58.7 & 52.7 & 35 & 31 & 19 & 17.2 & 13.5 & 9.2 & 8.2 & 0.5 & 0.2 \\
\hline
\end{tabular}

aRepresents age of grapevines in years at time of sampling in 2017. 
the other two came from two other nurseries. This indicates that virus infections in Vignoles may have more in common with other Vignoles vineyards across the state, rather than with virus infections of other cultivars planted adjacent to Vignoles.

The types of viruses detected in Norton were distinctly different from Vignoles (Table 6). In contrast to Vignoles, GRSPaV and GLRaV-2 were absent from all samples. Furthermore, GRBV and GLRaV-2RG were detected in $77.5 \%$ and $72.5 \%$ of the composite Norton samples, respectively; these two viruses were nearly absent from Vignoles composite samples. The only virus that was detected at a high level in both Norton and Vignoles was GLRaV-3, at $85.0 \%$ and $88.5 \%$, respectively. Virus combinations unique to Norton (i.e., not found with other cultivars) are highlighted with bold lettering (Table 6). All of the Norton composite samples contained at least one virus, and $92.5 \%$ carried two or more viruses. Of samples that contained more than one virus, all contained some combination of GRBV, GLRaV-3, and GLRaV-2RG; $42.5 \%$ of the Norton samples contained all three viruses (GRBV, GLRaV-3, and GLRaV-2RG), whereas another 50\% of the samples consisted of one of three combinations: GRBV and GLRaV-2RG, GLRaV-3 and GLRaV2RG, or GLRaV-3 and GRBV (Table 6).

The types of viruses detected in Vidal blanc were a mixture of elements from both Vignoles and Norton (Table 7). For example, GRSPaV was detected in $100 \%$ of the Vidal blanc samples, similar to Vignoles, but a significant percentage (24\%) also carried GRBV. In addition, 91.1\% of the samples carried GLRaV-3. One characteristic that distinguished Vidal blanc from both Norton and Chambourcin was that one-third of the samples contained GVCV. In addition, Vidal blanc had one of the highest infection rates for GLRaV-2 (at 91.1\%). As with Vignoles and Norton, most of the virus combinations detected in Vidal blanc were unique to that cultivar (Table 7, highlighted with bold lettering).

The presence of viruses in grapevine cultivars is thought to be closely associated with dissemination of infected planting material. By contrast, if virus prevalence were driven largely by spread after planting, then viruses should be found together randomly in all cultivars, in proportion to their prevalence in the survey. This second assumption was tested for each cultivar at each vineyard individually using a permutation-based goodness-of-fit test. Substantial deviations from expected patterns were observed when all cultivars were tested together $(p=0.010)$; this significance was driven by the significant $(p=0.003)$ difference for Vignoles. All other cultivars tested (Norton, Vidal blanc, Chambourcin, and Chardonel) did not show statistical significance at $\alpha=0.05$. These results suggest that, at least for Vignoles, it is unlikely that virus spread after planting is responsible for the virus combinations detected in Vignoles.

To further evaluate whether viruses are spreading throughout cultivars within a vineyard or through infected cultivar planting material, two different models of virus spread were compared. In the first (model 1), the virus pattern was assumed to be consistent in the different cultivars at a particular vineyard, but may differ across vineyards. In the second (model 2), the virus pattern was assumed to be consistent within a particular cultivar, regardless of the vineyard where

Table 5 Virus composition present in Vignoles composite samples at each of seven vineyard survey sites.

\begin{tabular}{|c|c|c|c|c|c|c|c|c|c|}
\hline Viruses & $\begin{array}{c}\text { Central }^{\mathrm{a}} \\
\text { Site } 2\end{array}$ & $\begin{array}{l}\text { Herm. } \\
\text { Site } 2\end{array}$ & $\begin{array}{l}\text { Herm. } \\
\text { Site } 7\end{array}$ & $\begin{array}{l}\text { Herm. } \\
\text { Site } 3\end{array}$ & $\begin{array}{l}\text { Herm. } \\
\text { Site } 1\end{array}$ & $\begin{array}{l}\text { Ozark } \\
\text { Site } 1\end{array}$ & $\begin{array}{l}\text { South } \\
\text { Site } 1\end{array}$ & Total $^{\mathrm{b}}$ & $\begin{array}{l}\text { Total in } \\
\text { entire } \\
\text { survey }\end{array}$ \\
\hline GRSPaV, GLRaV-3 & & & & & & & 1 & 1 & 6 \\
\hline GRSPaV, GVE & & & 1 & & & & & 1 & 1 \\
\hline GRSPaV, GVCV & & & & & & & 1 & 1 & 3 \\
\hline GRSPaV, GLRaV3, GVE & & 2 & 1 & 1 & & 1 & 2 & 7 & 8 \\
\hline GRSPaV, GLRaV-3, GVB ${ }^{\mathrm{d}}$ & & & & & & 1 & 1 & 2 & 2 \\
\hline GRSPaV, GLRaV-3, GFkV, GVE & 3 & 3 & 1 & 1 & & & & 8 & 8 \\
\hline GRSPaV, GLRaV-3, GFkV, GVB & & & 1 & & & & & 1 & 1 \\
\hline GRSPaV, GLRaV-3, GVB, GVE & 6 & 6 & 1 & 3 & 5 & & & 21 & 21 \\
\hline GRSPaV, GLRaV-3, GLRaV-2, GVE & & 1 & 1 & & & & & 2 & 5 \\
\hline GRSPaV, GLRaV-3, GRBV, GVE & & 3 & & & & & & 3 & 6 \\
\hline GRSPaV, GLRaV-3, GFkV, GVB, GVE & 1 & 4 & 1 & & 2 & & & 8 & 8 \\
\hline GRSPaV, GLRaV-3, GLRaV-2, GFkV, GVB & & & & 1 & & & & 1 & 1 \\
\hline GRSPaV, GLRaV-3, GLRaV-2, GFkV, GVE & & & & 3 & & 1 & & 4 & 5 \\
\hline GRSPaV, GLRaV-3, GLRaV-2, GVB, GVE & & 1 & & & & & & 1 & 1 \\
\hline GRSPaV, GLRaV-2, GLRaV-2RG, GFkV, GVB & & & 1 & 1 & 1 & 2 & & 5 & 5 \\
\hline GRSPaV, GLRaV-3, GLRaV-2, GFkV, GVB, GVE & & & 2 & & 2 & & & 4 & 4 \\
\hline Total \# samples collected at each location & 10 & 20 & 10 & 10 & 10 & 5 & 5 & 70 & 84 \\
\hline
\end{tabular}

a Sites are referred to by the Missouri grapegrowing region. Central, Hermann (Herm.), Ozark, Southeast (South).

${ }^{\mathrm{b}}$ The total number of samples detected in Vignoles $(n=70)$ with that specific virus combination.

${ }^{\mathrm{c}}$ The total number of samples detected in the entire survey $(n=400)$ with that specific virus combination.

dVirus combinations highlighted in bold are unique to Vignoles. 
the cultivar was found. Likelihood ratio testing of these two models indicates that while model 2 is far better than model 1 , neither model adequately describes the observed data $(p<$ 0.001 and $p=0.005$ using models 1 and 2 as the null model, respectively). The improved fit for the cultivar model may be due at least in part to resistance of some cultivars to specific viruses when other cultivars are susceptible.

Because neither of the previously examined models provided good fit to these data, an additional model was considered. This model (model 3 ) is identical to the cultivar model 2, except that it has a separate virus distribution for Norton grapes in one location. The vines tested at this location were planted $\sim 156$ years ago, and their virus pattern seems to be distinct from younger Norton vines (Table 6, Herman Site 1). Model 3 provides a statistically significantly better fit to these data than the cultivar-based model identified previously (model 2 ) and acceptable fit to these data $(p<0.001$ and $p=0.41$ for using model 2 and model 3 as the null model, respectively).

\section{Discussion}

This study is the first comprehensive survey for grapevine viruses in Missouri vineyards, providing updated information for grapevine viruses in the Midwest and also for viruses found in hybrid grape cultivars. We found that $90 \%$ of the 400 composite samples were infected with at least one virus, and $65 \%$ of the samples contained two or more viruses. These results are similar to a survey of $V$. vinifera in Ontario, in which $95.6 \%$ of the composite samples were infected with one virus and $71.7 \%$ carried two or more viruses (Xiao et al. 2018). Xiao et al. (2018) suggested that the high incidence of virus infections detected in their study was likely due to the use of infected planting material, and our study is in agreement with their analysis.

In our study, we noted that grapevine cultivars appeared to be infected by specific virus combinations that are, for the most part, unique to that cultivar. Most vineyards in our survey consisted of two to seven different hybrid grape cultivars at a single location. Remarkably, virus combinations found in one cultivar had more in common with the same cultivar at other vineyards across the state rather than with different cultivars located within the same vineyard. These patterns suggest that virus distribution in a cultivar was driven more by the presence of the virus in the initial planting material rather than due to spread of the virus by a vector after planting. To examine whether the presence of one virus in a sample affected the likelihood of seeing other viruses, we did a permutation test of goodness-of-fit (Fişek and Barlas 2013). The hypothesis (model 1), which tested the likelihood that viruses should be found together randomly in all cultivars, was rejected for Vignoles $(p=0.003)$. The variations observed in the other cultivars-Norton, Vidal blanc, and Chambourcinwere not significant. However, the virus pattern in one Norton vineyard that was planted over 156 years ago appeared to be distinctly different from the other four more recently planted sites. A third model, which separated out the 156-year-old Norton planting from the other sites, provided a significantly

Table 6 Virus composition present in Norton composite samples at each of six vineyard survey sites.

\begin{tabular}{|c|c|c|c|c|c|c|c|c|}
\hline Viruses & $\begin{array}{c}\text { Central }^{\mathrm{a}} \\
\text { Site } 2^{2}\end{array}$ & $\begin{array}{l}\text { Herm. } \\
\text { Site } 1\end{array}$ & $\begin{array}{c}\text { Herm. } \\
\text { Site 6a }\end{array}$ & $\begin{array}{c}\text { Herm. } \\
\text { Site } 6 b\end{array}$ & $\begin{array}{l}\text { South } \\
\text { Site } 1\end{array}$ & $\begin{array}{l}\text { Central } \\
\text { Site } 1\end{array}$ & Total $^{\mathrm{b}}$ & $\begin{array}{c}\text { Total in } \\
\text { entire } \\
\text { survey }\end{array}$ \\
\hline GLRaV-2RG & 1 & & & & & & 1 & 1 \\
\hline GLRaV-3 & 1 & & & & & & 1 & 7 \\
\hline GRBV & & & & & 1 & & 1 & 31 \\
\hline GLRaV-3, GRBV & 1 & & & & 1 & 2 & 4 & 7 \\
\hline GRBV, GLRaV-2RG ${ }^{\mathrm{d}}$ & & & & & 3 & 1 & 4 & 4 \\
\hline GLRaV-3, GRBV, GLRaV-2RG & & & 2 & & 2 & & 4 & 4 \\
\hline GLRaV-3, GRBV, GVB & 1 & & & & & 1 & 2 & 2 \\
\hline GLRaV-3, GRBV, GVE & 1 & & & & 1 & & 2 & 3 \\
\hline GLRaV-3, GRBV, GFkV & & & & & & 1 & 1 & 1 \\
\hline GLRaV-3, GLRaV-2RG, GVB & & & 1 & & & & 1 & 1 \\
\hline GLRaV-3, GLRaV-2RG, GVE & & 5 & & & & & 5 & 5 \\
\hline GLRaV-3, GRBV, GLRaV-2RG, GVB & 3 & & & & 1 & & 4 & 4 \\
\hline GLRaV-3, GRBV, GLRaV-2RG, GVE & & & & 4 & & & 4 & 4 \\
\hline GLRaV-3, GLRaV-2RG, GFkV, GVB & 1 & & & & & & 1 & 1 \\
\hline GLRaV-3, GRBV, GLRaV-2RG, GFkV & & & 1 & 1 & & & 2 & 2 \\
\hline GLRaV-3, GRBV, GLRaV-2RG, GFkV, GVB & & & 1 & & & & 1 & 1 \\
\hline GLRaV-3, GRBV, GLRaV-2RG, GFkV, GVA & 1 & & & & & & 1 & 1 \\
\hline GLRaV-3, GRBV, GLRaV-2RG, GFkV, GVE & & & & & 1 & & 1 & 1 \\
\hline Total & 10 & 5 & 5 & 5 & 10 & 5 & 40 & \\
\hline
\end{tabular}

aSites are referred to by the Missouri grapegrowing region. Central, Hermann (Herm.), Southeast (South).

${ }^{\text {b}}$ The total number of samples detected in Norton $(n=40)$ with that specific virus combination.

'The total number of samples detected in the entire survey $(n=400)$ with that specific virus combination.

dVirus combinations highlighted in bold are unique to Norton. 
better fit for the data, providing further evidence that virus combinations are cultivar-specific.

There is, however, compelling evidence that at least one virus, GVCV, is spreading among some cultivars in Missouri. GVCV can infect both the wild grape $V$. rupestris and $A$. cordata (Beach et al. 2017, Peterson et al. 2019). Both species are commonly found throughout Missouri, and Peterson et al. (2019) showed that GVCV is well established in these species. In a survey of $113 \mathrm{~A}$. cordata samples collected from three Midwest states, $31 \%$ of $A$. cordata were positive for GVCV (Peterson et al. 2019). Furthermore, the grape aphid (Aphis illinoisensis), an insect ubiquitous in Missouri, can transmit GVCV from A. cordata to Chardonel. Consequently, a substantial reservoir of GVCV exists in Missouri and surrounding Midwest states, and an insect vector has been proven capable of transmission of GVCV to cultivated grapes (Beach et al. 2017, Peterson et al. 2019). Nonetheless, GVCV was detected in only seven of 25 cultivars in our survey. GVCV was found in a substantial number of the composite samples of Vidal blanc and Chardonel, as well as in other cultivars such as Valvin Muscat, Cayuga, Noiret, and Viognier (Table 2). However, it was striking to see that the virus was absent from all red-berried cultivars, with the exception of one sample of Noiret (Table 2). The cultivars Chambourcin and Norton have been shown to be resistant to GVCV (Guo et al. 2014, Qiu et al. 2020); it may be that other red cultivars are also resistant.

One surprising result of the survey was that GRBV is present in a broad range of hybrid grape cultivars grown in Mis- souri. Prior to 2017, GRBV had only been found in the cultivar Crimson Cabernet; its discovery in this cultivar in 2016 was facilitated by the appearance of the classic symptoms late in the growing season that are associated with GRBV infection (Schoelz et al. 2019). In the 2017 survey, GRBV was detected in 15 of the 25 hybrid grape cultivars sampled and in a high proportion of samples. For example, GRBV was detected in $77 \%$ of the Norton composite samples, and was found in five of the six Norton vineyard blocks included in the survey (Table 6). The one exception was a 0.85 -acre block of Norton that was planted before the Civil War: all five composite samples contained GLRaV-3, GLRaV-2RG, and GVE, but GRBV was absent (Table 6). Forty individual vines, approximately one-third of the Norton vines in the same block, were sampled for GRBV in 2018, and GRBV was not detected in any samples (Table 3). Although GRBV was only recently recognized as a distinct disease agent in 2008 and the virus genome characterized in 2012 (Krenz et al. 2012, Al Rwahnih et al. 2013), its presence in germplasm repositories indicated its presence in California vineyards as early as 1940 (Al Rwahnih et al. 2015, Thompson et al. 2018). It is interesting that GRBV was absent from the Norton vines planted before the Civil War and that this block remained free of GRBV. Within the same vineyard there were two blocks of Chardonel, and GRBV was readily detected in both blocks in the 2017 survey. Consequently, it does not appear that GRBV was transmitted to this Norton block by any insect vector, even though the virus was present within the same vineyard. Studies are underway now to determine the prevalence of

Table 7 Virus composition present in Vidal blanc composite samples at each of five vineyard survey sites.

\begin{tabular}{|c|c|c|c|c|c|c|c|}
\hline Viruses & $\begin{array}{l}\text { Herm }_{i}{ }^{a} \\
\text { Site } 1\end{array}$ & $\begin{array}{l}\text { Aug. } \\
\text { Site } 2\end{array}$ & $\begin{array}{l}\text { Aug. } \\
\text { Site } 3\end{array}$ & $\begin{array}{l}\text { Aug. } \\
\text { Site } 4\end{array}$ & $\begin{array}{l}\text { Ozark } \\
\text { Site } 1\end{array}$ & Total $^{\mathrm{b}}$ & $\begin{array}{c}\text { Total in } \\
\text { entire } \\
\text { survey }^{\mathrm{c}}\end{array}$ \\
\hline GRSPaV, GLRaV-3 & & & & & 2 & 2 & 6 \\
\hline GRSPaV, GLRaV-2 & 3 & & & & & 3 & 7 \\
\hline GRSPaV, GLRaV-3, GLRaV-2 $^{\mathrm{d}}$ & 3 & 1 & 1 & & 1 & 6 & 6 \\
\hline GRSPaV, GLRaV-3, GFkV & & & & & 2 & 2 & 2 \\
\hline GRSPaV, GLRaV-2, GVCV & 1 & & & & & 1 & 1 \\
\hline GRSPaV, GLRaV-3, GLRaV-2, GFkV & 2 & & & & 5 & 7 & 7 \\
\hline GRSPaV, GLRaV-3, GLRaV-2, GVE & & 1 & & 2 & & 3 & 5 \\
\hline GRSPaV, GLRaV-3, GLRaV-2, GVCV & 1 & 4 & & & & 5 & 5 \\
\hline GRSPaV, GLRaV-3, GLRaV-2, GRBV & & & 1 & & & 1 & 1 \\
\hline GRSPaV, GLRaV-3, GLRaV-2, GRBV, GFkV & & & & 1 & & 1 & 1 \\
\hline GRSPaV, GLRaV-3, GLRaV-2, GRBV, GVE & & & & 4 & & 4 & 4 \\
\hline GRSPaV, GLRaV-3, GLRaV-2, GRBV, GVCV & & 1 & & & & 1 & 1 \\
\hline GRSPaV, GLRaV-3, GLRaV-2, GVCV, GVE & & 2 & & 1 & & 3 & 3 \\
\hline GRSPaV, GLRaV-3, GLRaV-2, GVCV, GFkV & & 1 & & & & 1 & 1 \\
\hline GRSPaV, GLRaV-3, GLRaV-2, GRBV, GVCV, GFkV & & & 1 & & & 1 & 3 \\
\hline GRSPaV, GLRaV-3, GLRaV-2, GRBV, GVCV, GVE & & & 1 & 2 & & 3 & 3 \\
\hline GRSPaV, GLRaV-3, GLRaV-2, GRBV, GVCV, GFkV, GVE & & & 1 & & & 1 & 1 \\
\hline Total & 10 & 10 & 5 & 10 & 10 & 45 & \\
\hline
\end{tabular}

a Sites are referred to by the Missouri grapegrowing region. Hermann (Herm.), Augusta (Aug.), Ozark.

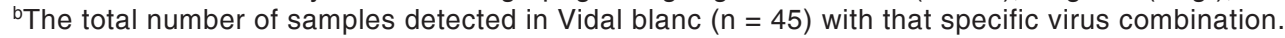

${ }^{c}$ The total number of samples detected in the entire survey $(n=400)$ with that specific virus combination.

${ }^{d}$ Virus combinations highlighted with bold lettering are unique to Vidal blanc. 
the three-cornered alfalfa hopper vector (Bahder et al. 2016, Cieniewicz et al. 2018) or whether alternate vectors for GRBV might exist.

One unexpected result of the 2017 survey was that no nematode-transmitted viruses, represented by GFLV, ToRSV, TRSV, and ArMV (Table 1), were detected in any of the 400 samples, even though an earlier survey of five Missouri vineyards found the presence of ToRSV and ArMV (Milkus 2001). ToRSV typically induces poor berry set and size in berry clusters (Rowhani et al. 2017), symptoms that were observed during collection of samples in Vidal blanc and Chardonel in the 2017 survey. Furthermore, the presence of ToRSV was confirmed by ELISA in one Vidal blanc vineyard in 2016 and again in 2018 (Schoelz and Volenberg, unpublished), even though the RT-qPCR assay failed to detect the virus in the same vineyard in 2017. One possibility is that we failed to detect ToRSV in the 2017 survey because the nucleotide sequence targeted by RT-qPCR differs enough from the ToRSV strains in Missouri such that ToRSV sequences were not amplified. Further efforts are now directed towards the characterization of ToRSV isolates present in that Vidal blanc vineyard.

Of all of the viruses detected in our survey, the two considered to cause the most economic damage nationwide are GLRaV-3 and GRBV. GLRaV-3 is considered the primary causal agent of grapevine leafroll disease (GLD), the most important virus disease of grapevines (Maree et al. 2013). Symptoms of GLD are most prominent in red-berried cultivars of $V$. vinifera, as symptomatic leaves accumulate anthocyanin pigments due to induction of the anthocyanin biosynthetic pathway (Gutha et al. 2010), which causes the leaves to turn reddish-purple. Typically, a narrow band of tissue along the major veins remains green (Naidu et al. 2014, Burger et al. 2017) in symptomatic leaves. By contrast, white-berried cultivars may show mild yellowing. Both red- and white-berried cultivars may also exhibit a downward curling of the leaf margins. Symptoms may begin in the bottom of the canopy as early as veraison, but symptom development is dependent on a number of factors, including the cultivar, the choice of scion and rootstock, and the environment. In contrast to $V$. vinifera, symptoms of GLD have not been observed in American grape species and in hybrids, even though there is no evidence of resistance in these Vitis species.

The effect of GLD on vine physiology has been studied extensively, as summarized in Reynolds (2017). In $V$. vinifera, GLD has been shown to affect vine health in a number of ways, including a reduction in photosynthesis and reductions in cluster number, cluster weight, berry weight, and vine size. GLD may also affect fruit quality through delays in fruit maturity, as well as through alterations in soluble solids, titratable acids, total phenolics, and total tannins (Naidu et al. 2014, Burger et al. 2017). Based on studies on $V$. vinifera grown on the West Coast and New York, the potential economic impact could be significant. One study conducted in the Finger Lakes region of New York estimated losses associated with GLRaV-3 at $\$ 25,000$ to $\$ 40,000$ per hectare in Cabernet franc vineyards (Atallah et al. 2012), with comparable estimated losses for Cabernet Sauvignon and Merlot vineyards in California and Washington (Ricketts et al. 2015).

The economic impact of GRBV is comparable to GLRaV-3. GRBV induces red coloration in leaves of red-berried $V$. vinifera cultivars, with symptoms first appearing in older leaves late in the season (Cieniewicz et al. 2017). Leaves with strong symptoms may prematurely drop off the vine. In white-berried cultivars, leaves may develop chlorosis that turns necrotic as the season progresses. GRBV also is known to delay fruit ripening, altering carbon translocation away from berries, reducing the total soluble solids, and decreasing Brix in fruit and anthocyanin contents in berry skin (Blanco-Ulate et al. 2017, Cieniewicz et al. 2017, Martínez-Lüscher et al. 2019). Symptoms in red-berried cultivars caused by GRBV may be confused with GLRaV-3, but also could be similar to abiotic stresses that include magnesium or potassium nutrient deficiencies. Ricketts et al. (2017) estimated that the economic impact of GRBV could be as much as $\$ 68,548$ per hectare over the life span of a vineyard.

Both GRBV and GLRaV-3 were detected in a broad range of hybrid grapes grown in Missouri, but there currently is a gap in our knowledge concerning the impact of these viruses on the types of grape hybrid cultivars grown in Missouri. In fact, only one study has examined the influence of virus infections on hybrid grapes. Kovacs et al. (2001) examined the impact of GLRaV-3 on Vidal blanc and St. Vincent cultivars, showing that GLRaV-3 caused a reduction in berry weight and an increase in titratable acid levels. In our study, we could reliably observe GRBV symptoms in the cultivar Crimson Cabernet and perhaps Chambourcin. We have not been able to confirm any symptoms that would be diagnostic of GRBV infection in Norton. Further research will be necessary to examine the impact of GRBV and GLRaV-3 on the physiology and berry quality of the hybrid grape cultivars grown in the environmental conditions common to Missouri.

\section{Conclusion}

This study is the first comprehensive survey for grapevine viruses in Missouri vineyards, providing some of the first survey information for grapevine viruses in the Midwest and also for viruses found in hybrid grape cultivars. Previous surveys for viruses of grapevines in Missouri were of limited scope and did not provide a comprehensive assessment of different cultivars in vineyards across the state. Of the 400 composite samples included in our survey, $90 \%$ were infected with at least one virus and $65 \%$ contained two or more. GVCV, a virus that was discovered in Missouri, was primarily detected in white-berried cultivars, with moderate levels of infection in Vidal blanc, Chardonel, and Valvin Muscat. GRBV was prevalent in a majority of the grape cultivars surveyed, as it was detected in 15 of the 25 grape cultivars and at 28 locations across Missouri. Interestingly, GRBV was detected in $77 \%$ of the Norton samples, but was absent from a 0.85 -acre block of Norton that was planted before the Civil War, which indicates a limited opportunity for spread of the virus at that location. Similarly, grapevine leafroll viruses were prevalent in a majority of the hybrid grape cultivars 
sampled. Although a high percentage of samples were infected with GLRaV-3 and/or GRBV, the hybrid grapes grown in Missouri did not exhibit the red leaf symptoms that are readily observed in $V$. vinifera cultivars. It is important now to examine the impact these viruses may have on hybrid vine health and berry quality.

\section{Literature Cited}

Al Rwahnih M, Osman F, Sudarshana M, Uyemoto J, Minafra A, Saldarelli P, Martelli G and Rowhani A. 2011. Detection of Grapevine leafroll-associated virus 7 using real time qRT-PCR and conventional RT-PCR. J Virol Methods 179:383-389.

Al Rwahnih M, Ashita MD, Anderson MM, Rowhani A, Uyemoto JK and Sudarshana MR. 2013. Association of a DNA virus with grapevines affected by red blotch disease in California. Phytopathology 103:1069-1076.

Al Rwahnih M, Rowhani A and Golino D. 2015. First report of Grapevine red blotch-associated virus in archival grapevine material from Sonoma County, California. Plant Dis 99:895.

Al Rwahnih M, Golino D and Rowhani A. 2016. First report of Grapevine Pinot gris virus infecting grapevine in the United States. Plant Dis 100:1030.

Atallah SS, Gómez MI, Fuchs MF and Martinson TE. 2012. Economic impact of grapevine leafroll disease on Vitis vinifera cv. Cabernet franc in Finger Lakes vineyards of New York. Am J Enol Vitic 63:73-79.

Bahder BW, Zalom FG, Jayanth M and Sudarshana MR. 2016. Phylogeny of geminivirus coat protein sequences and digital PCR aid in identifying Spissistilus festinus as a vector of grapevine red blotchassociated virus. Phytopathology 106:1223-1230.

Beach S, Kovens M, Hubbert L, Honesty S, Guo Q, Pap D, Dai R, Kovacs L and Qiu W. 2017. Genetic and phenotypic characterization of Grapevine vein clearing virus from wild V. rupestris. Phytopathology 107:138-144.

Blanco-Ulate B et al. 2017. Red blotch disease alters grape berry development and metabolism by interfering with transcriptional and hormonal regulation of ripening. J Exp Bot 68:1225-1238.

Burger JT, Maree HJ, Gouveia P and Naidu RA. 2017. Grapevine leafroll-associated virus 3. In Grapevine Viruses: Molecular Biology, Diagnostics and Management. Meng B et al. (eds), pp. 167-195. Springer International Publishing AG, Cham, Switzerland.

Calvi BL. 2011. Effects of red-leaf disease on Cabernet Sauvignon at the Oakville Experimental vineyard and mitigation by harvest delay and crop adjustment. University of California, Davis, CA.

Cieniewicz E, Perry K and Fuchs M. 2017. Grapevine red blotch: Molecular biology of the virus and management of the disease. In Grapevine Viruses: Molecular Biology, Diagnostics and Management. Meng B et al. (eds), pp. 303-314. Springer International Publishing AG, Cham, Switzerland.

Cieniewicz EJ, Pethybridge SJ, Loeb G, Perry K and Fuchs M. 2018. Insights into the ecology of Grapevine red blotch virus in a diseased vineyard. Phytopathology 108:94-102.

Diaz-Lara A et al. 2018. Characterization of Grapevine leafrollassociated virus 3 genetic variants and application towards RT-qPCR assay design. PLoS ONE 13:e0208862.

Fişek MH and Barlas Z. 2013. Permutation tests for goodness-of-fit testing of mathematical models to experimental data. Soc Sci Res 42:482-495.

Fuchs M. 2020. Grapevine viruses: A multitude of diverse species with simple but overall poorly adopted management solutions in the vineyard. J Plant Pathol 102:643-653.
Guo Q, Honesty S, Xu ML, Zhang Y, Schoelz J and Qiu W. 2014. Genetic diversity and tissue and host specificity of Grapevine vein clearing virus. Phytopathology 104:539-547.

Gutha LR, Casassa LF, Harbertson JF and Naidu RA. 2010. Modulation of flavonoid biosynthetic pathway genes and anthocyanins due to virus infection in grapevine (Vitis vinifera) leaves. BMC Plant Biol 10:187.

Hodgetts J, Boonham N, Mumford R and Dickinson M. 2009. Panel of $23 \mathrm{~S}$ rRNA gene-based real-time PCR assays for improved universal and group-specific detection of phytoplasmas. Appl Environ Microbiol 75:2945-2950.

Kovacs LG, Hanami H, Fortenberry M and Kaps ML. 2001. Latent infection by leafroll agent GLRaV-3 is linked to lower fruit quality in French-American hybrid grapevines Vidal blanc and St. Vincent. Am J Enol Vitic 52:254-259.

Krenz B, Thompson JR, Fuchs M and Perry KL. 2012. Complete genome sequence of a new circular DNA virus from grapevine. J Virol 86:7715.

Krenz B, Thompson JR, McLane HL, Fuchs M and Perry KL. 2014. Grapevine red blotch-associated virus is widespread in the United States. Phytopathology 104:1232-1240.

Lewis F, Butler A and Gilbert L. 2011. A unified approach to model selection using the likelihood ratio test. Methods Ecol Evol 2:155-162.

Maree HJ et al. 2013. Grapevine leafroll-associated virus 3. Front Microbiol 4:82.

Martelli GP. 2017. An overview on grapevine viruses, viroids, and the diseases they cause. In Grapevine Viruses: Molecular Biology, Diagnostics and Management. Meng B et al. (eds), pp. 31-46. Springer International Publishing AG, Cham, Switzerland.

Martínez-Lüscher J et al. 2019. Grapevine red blotch virus may reduce carbon translocation leading to impaired grape berry ripening. J Agric Food Chem 67:2437-2448.

Milkus BN. 2001. Incidence of four NEPO viruses in Missouri vineyards. Am J Enol Vitic 52:56-57.

Milkus BN and Goodman RN. 1999. A survey of Missouri vineyards for the presence of five grape viruses. Am J Enol Vitic 50:133-134.

Naidu RA, Rowhani A, Fuchs M, Golino D and Martelli GP. 2014. Grapevine leafroll: A complex viral disease affecting a high-value fruit crop. Plant Dis 98:1172-1185.

Osman F and Rowhani A. 2006. Application of a spotting sample preparation technique for the detection of pathogens in wood plants by RT-PCR and real-time PCR (TaqMan). J Virol Methods 133:130-136.

Osman F and Rowhani A. 2008. Real-time RT-PCR (TaqMan ${ }^{\circledR}$ ) assays for the detection of viruses associated with Rugose wood complex of grapevine. J Virol Methods 154:69-75.

Osman F, Leutenegger C, Golino D and Rowhani A. 2007. Real-time RT-PCR (TaqMan ${ }^{\circledR}$ ) assays for the detection of Grapevine leafroll associated viruses 1-5 and 9. J Virol Methods 141:22-29.

Osman F, Leutenegger C, Golino D and Rowhani A. 2008. Comparison of low-density arrays, RT-PCR and real-time TaqMan ${ }^{\circledR}$ RT-PCR in detection of grapevine viruses. J Virol Methods 149:292-299.

Osman F, Hodzic E, Omanska-Klusek A, Olineka T and Rowhani A. 2013. Development and validation of a multiplex quantitative PCR assay for the rapid detection of Grapevine virus $A, B$ and $D$. J Virol Methods 194:138-145.

Peterson SM, Keith C, Austin K, Howard S, Su L and Qiu W. 2019. A natural reservoir and transmission vector of Grapevine vein clearing virus. Plant Dis 103:571-577.

Qiu W, Avery JD and Lunden S. 2007. Characterization of a severe virus-like disease in Chardonnay grapevines in Missouri. Plant Health Prog. doi:10.1094/PHP-2007-1119-01-BR. 
Qiu W, Peterson SM and Howard S. 2020. North American grape 'Norton' is resistant to Grapevine vein clearing virus. Plant Dis. doi.org/10.1094/PDIS-10-19-2161-SC.

Reynolds AG. 2017. The grapevine, viticulture, and winemaking: A brief introduction. In Grapevine Viruses: Molecular Biology, Diagnostics and Management. Meng B et al. (eds), pp. 3-29. Springer International Publishing AG, Cham, Switzerland.

Ricketts KD et al. 2015. Reducing the economic impact of grapevine leafroll disease in California: Identifying optimal disease management strategies. Am J Enol Vitic 66:138-147.

Ricketts KD, Gómez MI, Fuchs MF, Martinson TE, Smith RJ, Cooper ML, Moyer MM and Wise A. 2017. Mitigating the economic impact of grapevine red blotch: Optimizing disease management strategies in U.S. vineyards. Am J Enol Vitic 68:127-135.

Rowhani A, Daubert SD, Uyemoto JK and Al Rwahnih M. 2017. American Nepoviruses. In Grapevine Viruses: Molecular Biology, Diagnostics and Management. Meng B et al. (eds), pp. 109-126. Springer International Publishing AG, Cham, Switzerland.

Schaad NW, Opgenorth D and Gaush P. 2002. Real-time polymerase chain reaction for one-hour on-site diagnosis of Pierce's disease of grape in early season asymptomatic vines. Phytopathology 92:721-728.
Schoelz JE, Adhab M, Qiu W, Peterson S and Volenberg D. 2019. First report of red blotch virus in hybrid grapes in Missouri. Plant Dis 103:379.

Thompson T, Peterson S, Londo J and Qiu WP. 2018. First report of Grapevine red blotch virus in seven Vitis species in a U.S. Vitis germplasm repository. Plant Dis 102:828.

USDA National Agricultural Statistics Service Missouri. 2016. Missouri Grape Facts. https://missouriwine.org/sites/default/files/2016\%20 Grape\%20Facts_0.pdf.

Williams DA. 1970. Discrimination between regression models to determine the pattern of enzyme synthesis in synchronous cell cultures. Biometrics 26:23-32.

Xiao H, Shabanian M, Moore C, Li C and Meng B. 2018. Survey for major viruses in commercial Vitis vinifera wine grapes in Ontario. Virol J 15:127.

Yepes LM, Cieniewicz E, Krenz B, McLane H, Thompson JR, Perry KL and Fuchs M. 2018. Causative role of Grapevine red blotch virus in red blotch disease. Phytopathology 108:902-909.

Zhang Y, Singh K, Kaur R and Qiu W. 2011. Association of a novel DNA virus with the grapevine vein-clearing and vine decline syndrome. Phytopathology 101:1081-1090. 